\title{
EFFECTS OF FEEDING MUNG BEANS (VIGNARADIATE) ON THE BROILER PERFORMANCE
}

\author{
ROZHGAR BAYIZ SAEED \\ Faculty of Agricultural Sciences, Sulaimani University.
}

Received: 17 July 2016; Accepted: 19 September 2016

\begin{abstract}
This experiment was carried out at the poultry research farm belonging to Faculty of Agriculture Science, Sulaimani University Bakrajo during the period from 24/10/2014 to 10/12/2014. This experiment was designed to study the effect of feeding different levels of mung beans (Vignaradiata) on the broiler performance. A total of 99 one-day old broiler chicks (ross 308) were randomly divided in to three experimental treatments with 3 replicates, each replicate contains 11 birds reared on floor cages. The first group was considered as (control) while the second group fed on diet, had 5\% mung bean and the third group, received diet contain 10\% mung bean. The effects of feeding mung beans at various two levels on the performance of young broiler chicks, for both trials there was no significant effect $(\mathrm{P} \geq 0.05)$ of diet contain mung beans on weight gain or feed conversion of broilers.
\end{abstract}

Key words: Mung beans, Broiler, Performance.

\section{INTRODUCTION}

Increase awareness of consumers to healthy and safe animal products as well as worldwide ban to use antibiotics has made natural feed additives being studied and used. Prebiotic and phytobiotic are several alternatives to in feed antibiotic which have been shown to improve broilers performance and health (Murwani, 2010). Using of grains such as corn, sorghum and mung beans provide not only macroand micro-nutrients but also other bioactive nutrients such as carotenoids in corn and mung beans and poliphenolic substance in sorghum and mung beans which can improve humoral immune response against vaccination (Awika et al., 2000; Murwani, 2008; Murwani and Murtini, 2009). Coccidiosis is recognized as the protozoal disease that has great economic impact on broiler production. It reduces feed consumption and thereby causes reduction of growth (Vegad, 2004 and Frolich et al., 2013). The relationship between diet composition and coccidiosis has been investigated and it has been proved that the dietary levels of various nutrients influence coccidial infection in poultry (Allen et al., 1998 and Singh et al., 2013b). Sprouted mung beans are rich in digestible energy (carbohydrates), bioavailable vitamins (B6 and C), chelated minerals ( $\mathrm{Ca}, \mathrm{Fe}, \mathrm{Mg}$,

Corresponding author: Dr. ROZHGAR BAYIZ SAEED

E-mail address: rozhgarbayzesaeed@yahoo.com

Present address: Faculty of Agricultural Sciences, Sulaimani University
P, K, Na, Zn, Cu, Mn, Se etc.), Omega-3 fatty acids, amino acids, proteins and beneficial enzymes. Many of these nutrients have well established role as anticoccidials. Due to their nutrient composition, these may be effective in controlling coccidiosis. However, there is scarcity of literature on this aspect. Mung bean hull is the seed coat covering the mung bean and it is abundantly available in Vietnam. Mung bean hull is characterized by a moderate level of crude protein $(12 \%)$ and crude fiber (19\%) which makes it suitable for inclusion in diets in pre-laying and laying hen. Moreover, the fiber content in Mung bean hull could reduce cholesterol in egg yolk, liver and plasma of laying hen (McNaughton 1978).

The objective of this study was the effect of mung bean inclusion in broiler diets on improvement of feat conversion, healthcare and growth of birds and reduce the incidence of non-microbial diseases and to investigate the of feat of adding mung beans to broiler diets on growth performance.

\section{MATERIALS AND METHODS}

The experimental was carried out at the poultry research farm belonging to Faculty of Agriculture Science, Sulaimani University in Bakrajo during the period from $24 / 10 / 2104$ to $5 / 12 / 2014$. This experiment was designed to study the effect of feeding different levels of mung beans (Vignaradiata) on broiler performance. A total of 99 one-day old broiler (Ross 308) chicks were randomly divided in 
three experimental treatments with 3 replicates, each replicate contains 11 birds reared on floor cages.

1 - First treatment assigned as the control to which the other treated groups were compared.

2 - Chicks in the Second group fed on diet contain 5\% crudemung bean.
3 - Birds in third treatment fed ad_libitum on diets contain $10 \%$ crudemung beans.

Birds fed on the two types of diets for each transaction as shown in table (1).

Table 1: Components of the experimental diets

\begin{tabular}{|c|c|c|c|c|c|c|}
\hline \multirow[t]{2}{*}{ Feed Component } & \multicolumn{2}{|c|}{ T1 } & \multicolumn{2}{|c|}{ T2 } & \multicolumn{2}{|c|}{ T3 } \\
\hline & $\begin{array}{c}\text { starter\% } \\
\text { (7-28 days) }\end{array}$ & $\begin{array}{c}\text { finisher\% } \\
(28-42)\end{array}$ & $\begin{array}{c}\text { starter\% } \\
\text { (7-28 days) }\end{array}$ & $\begin{array}{c}\text { finisher\% } \\
(28-42)\end{array}$ & $\begin{array}{c}\text { starter\% } \\
\text { (7-28 days) }\end{array}$ & $\begin{array}{c}\text { finisher\% } \\
(28-42)\end{array}$ \\
\hline Mung bean & $\mathbf{0}$ & $\mathbf{0}$ & 5 & 5 & 10 & 10 \\
\hline Soybean meal $44 \%$ & 28,5 & 24 & 26,5 & 22 & 24,5 & 19,5 \\
\hline Wheat & 15 & 15 & 15 & 15 & 15 & 15 \\
\hline Corn & 46,5 & 54 & 42,5 & 50 & 39 & 47 \\
\hline sun flower seed oil** & 2 & 2,5 & 3 & 3,5 & 3,5 & 4 \\
\hline protein concentrate* & 8 & 4,5 & 8 & 4,5 & 8 & 4,5 \\
\hline \multicolumn{7}{|c|}{ calculated Chemical composition } \\
\hline Crude Protein\% & 22,9 & 20 & 22,9 & 20 & 23 & 19,5 \\
\hline ME (kcal/kg) & 3045 & 3150 & 3033 & 3150 & 3017 & 3150 \\
\hline
\end{tabular}

*protein concentrate (Provimi -Jordan) components. were 44\% protein $2100 \mathrm{Kcal} / \mathrm{Kg} \mathrm{ME},(5 \%$ Fat, $2 \%$ Fiber, Calcium 6.5\%, phosphor 6\%, Lysine 3.85\%, Methionine 3.75\%, Met. + Cys 4\%, Sodium 2.3\%).

** Enriched With vitamin A,D.

Tested parameters: Live body weight and weight of individual chick were weighed with sensitive scale. Weight gain was calculated by subtracting the weight of the initial weight from the final weight for the following week as shown in the following.

weight gain $=$ final weight - initial weight. Feed Intake was calculated for each diet consumer repeater week, as shown in the following equation:

Average feed consumed $(\mathrm{g})=$ Feed provided at the beginning of the period $(\mathrm{g})$ - feed remaining in the final period $(\mathrm{g}) /$ The total number of birds / Repeater (hadme, 1994).

Feed conversion ratio was calculated by the following equation: Food conversion factor $=$ The average amount of diet consumed during the experimental period $(\mathrm{g}) /$ weight gain $(\mathrm{g})$.

Production Index was calculated by the following equation:

Production index $=$ mean of weight $\times$ availability $\backslash$ day $x$ feed efficiency $\times 100$

\section{Specific Carcass Characteristics}

The slaughter process has been manually andcut carcass into parts separately and follow the same method for each carcass.

Six randomly selected birds aged 35 and 42 days for each treatment were slaughtered. Pre slaughter weighted, weighted of dressing

Dressing Percentage $=$ carcass weight/ live weight $\times 100$
The proportion of the main piece of the carcass included a major breast and thigh and heart, liver and gizzard was calculated by the following equation:

Percentage of pieces (thigh and breast), (heart, liver and gizzard $)=$ weight of pieces $/$ carcass weight $\times 100$

Percentage of pancreas $=$ weight of pancreas $/$ live weight $\times 100$

\section{Statistical analysis}

Statistical analysis was performed for the first experimental data and implemented in accordance with the design of random full (CRD).

To study the treatment using the statistical program ready computer-XL stat, version 7.5 (2004) and depending on the mathematical model of the following

Yij $=\mu+\mathrm{TI}+\mathrm{eij}$

Differences among treatments were tested using Duncan's multiple range test (1955).

\section{RESULTS}

Effects of feeding mung beans at various levels on the performance of young broiler chickens are shown in Tables 2,3,4,5 and 6. For both trials there was no significant effect $(\mathrm{P}>.05)$ of diet on weight gain or feed conversion of broiler. 
Table 2: Body weight development $(\mathrm{g})$ as influenced by different dietary treatment (mean \pm stander error).

\begin{tabular}{|c|c|c|c|c|c|c|}
\hline $\begin{array}{l}\text { Week } \\
\text { Treatment }\end{array}$ & 1 & 2 & 3 & 4 & 5 & 6 \\
\hline $\mathrm{T} 1$ & $141.67^{\mathrm{a}} \pm 13.32$ & $389.39^{\mathrm{a}} \pm 13.317$ & $723.33^{\mathrm{a}} \pm 23.09$ & $1425.00^{\mathrm{a}} \pm 38.19$ & $2100.00^{\mathrm{a}} \pm 117.56$ & $2933.33^{\mathrm{a}} \pm 74.07$ \\
\hline $\mathrm{T} 2$ & $139.39^{\mathrm{a}} \pm 4.01$ & $380.30^{\mathrm{a}} \pm 4.009$ & $720.00^{\mathrm{a}} \pm 3.33$ & $1375.00^{\mathrm{a}} \pm 22.05$ & $2108.33^{\mathrm{a}} \pm 152.98$ & $3008.33^{\mathrm{a}} \pm 132.29$ \\
\hline $\mathrm{T} 3$ & $112.12^{\mathrm{b}} \pm 13.21$ & $350.00^{\mathrm{a}} \pm 13.209$ & $680.00^{\mathrm{a}} \pm 29.06$ & $1291.67^{\mathrm{a}} \pm 74.07$ & $1883.33^{\mathrm{a}} \pm 16.67$ & $2991.67^{\mathrm{a}} \pm 52.04$ \\
\hline
\end{tabular}

Table 3: Weekly Body weight gain $(\mathrm{g})$ as influenced by different dietary treatment (mean \pm stander error).

\begin{tabular}{lccccc}
\hline Week & $1-2$ & $2-3$ & $3-4$ & $4-5$ & $5-6$ \\
\cline { 3 - 6 } & & & & & \\
\hline $\mathrm{T} 1$ & $247.73^{\mathrm{a}} \pm 5.303$ & $333.94^{\mathrm{a}} \pm 5.612$ & $701.67^{\mathrm{a}} \pm 25.66$ & $675.00^{\mathrm{a}} \pm 117.56$ & $833.33^{\mathrm{a}} \pm 163.94$ \\
\hline $\mathrm{T} 2$ & $240.91^{\mathrm{a}} \pm 8.436$ & $339.70^{\mathrm{a}} \pm 12.313$ & ${ }^{\mathrm{a}} 655.00 \pm 21.67$ & $733.33^{\mathrm{a}} \pm 152.98$ & $900.00^{\mathrm{a}} \pm 252.21$ \\
\hline $\mathrm{T} 3$ & $237.88^{\mathrm{a}} \pm 4.545$ & $330.00^{\mathrm{a}} \pm 13.790$ & $611.67^{\mathrm{a}} \pm 45.31$ & $591.67^{\mathrm{a}} \pm 16.67$ & $1108.33^{\mathrm{a}} \pm 126.11$ \\
\hline
\end{tabular}

Table 4: Weekly feed intake (g/chick) as influenced by different dietary treatment (mean \pm stander error).

\begin{tabular}{lcccccc}
\hline \multicolumn{1}{c}{$\begin{array}{l}\text { Week } \\
\text { Treatment }\end{array}$} & 1 & 2 & 3 & 4 & 5 & 6 \\
\hline $\mathrm{T} 1$ & $130.30^{\mathrm{a}} \pm 14.50$ & $415.15^{\mathrm{a}} \pm 15.77$ & $309.09^{\mathrm{a}} \pm 20.71$ & $587.88^{\mathrm{a}} \pm 73.62$ & $1063.64^{\mathrm{a}} \pm 16.51$ & $1351.85^{\mathrm{a}} \pm 57.50$ \\
\hline $\mathrm{T} 2$ & $130.93^{\mathrm{a}} \pm 15.96$ & $376.64^{\mathrm{ab}} \pm 6.94$ & $303.16^{\mathrm{a}} \pm 5.46$ & $461.74^{\mathrm{a}} \pm 83.70$ & $1111.62^{\mathrm{a}} \pm 50.62$ & $1307.41^{\mathrm{a}} \pm 114.04$ \\
\hline $\mathrm{T} 3$ & $100.00^{\mathrm{a}} \pm 8.02$ & $359.09^{\mathrm{b}} \pm 31.82$ & $307.58^{\mathrm{a}} \pm 9.94$ & $490.91^{\mathrm{a}} \pm 52.57$ & $1124.24^{\mathrm{a}} \pm 8.02$ & $1329.63^{\mathrm{a}} \pm 68.59$ \\
\hline
\end{tabular}

Table 5: Weekly feed conversion index of broiler fed different experimental diets (mean \pm stander error).

\begin{tabular}{lccccc}
\hline & $1-2$ & $2-3$ & $3-4$ & $4-5$ & $5-6$ \\
\hline $\mathrm{T} 1$ & $1.68^{\mathrm{a}} \pm 0.05$ & $0.93^{\mathrm{a}} \pm 0.082$ & $0.84^{\mathrm{a}} \pm 0.10$ & $1.90^{\mathrm{a}} \pm 0.502$ & $2.40^{\mathrm{a}} \pm 0.24$ \\
\hline $\mathrm{T} 2$ & $1.57^{\mathrm{a}} \pm 0.08$ & $0.89^{\mathrm{a}} \pm 0.017$ & $0.70^{\mathrm{a}} \pm 0.15$ & $1.52^{\mathrm{a}} \pm 0.401$ & $1.46^{\mathrm{a}} \pm 1.20$ \\
\hline $\mathrm{T} 3$ & $1.51^{\mathrm{a}} \pm 0.12$ & $0.94^{\mathrm{a}} \pm 0.056$ & $0.81^{\mathrm{a}} \pm 0.08$ & $1.94^{\mathrm{a}} \pm 0.057$ & $1.22^{\mathrm{a}} \pm 0.10$ \\
\hline
\end{tabular}

Table 6: Production index as influenced by using of mungbeans (mean \pm stander error).

\begin{tabular}{ll}
\hline Treatment & 1 \\
\hline $\mathrm{T} 1$ & $602.24^{\mathrm{a}} \pm 113.31$ \\
\hline $\mathrm{T} 2$ & $509.52^{\mathrm{a}} \pm 184.76$ \\
\hline $\mathrm{T} 3$ & $452.86^{\mathrm{a}} \pm 46.34$ \\
\hline $\mathrm{T} 1$ control. \\
$\mathrm{T} 2$ used rawmung bean $5 \%$. \\
$\mathrm{T} 3:$ used raw mung bean $10 \%$ \\
$\times$ Different words meant that there is significant incorporeal under level $(\mathrm{P}<0.05)$
\end{tabular}


Table 7 Shown the effect of feeding of mung bean on live body weight and percentage of pancreas at 35 and 42 day. No significant differences were observed in body weight and percentage of pancreas. The knowledge that the using of mung beans did not adversely effect on the pancreas, and this is evidence of a good use of the $n$ broiler chickens.

Table 7: The effect of mung bean inclusion on live body weight and percentage of pancreas (mean \pm stander error)

\begin{tabular}{|c|c|c|c|c|}
\hline \multirow[t]{2}{*}{ treatment } & \multicolumn{2}{|c|}{ live body weight } & \multicolumn{2}{|c|}{ percentage of pancreas } \\
\hline & $35 \mathrm{~d}$ & $42 \mathrm{~d}$ & $35 d$ & $42 d$ \\
\hline $\mathrm{t} 1$ & $2120.00^{\mathrm{a}} \pm 110.81$ & $3360.00 \mathrm{a} \pm 96.95$ & $0.23^{\mathrm{a}} \pm 0.03$ & $0.17^{\mathrm{a}} \pm 0.01$ \\
\hline $\mathrm{t} 2$ & $2250.00^{\mathrm{a}} \pm 132.71$ & $2983.33 \mathrm{a} \pm 268.33$ & $0.24^{\mathrm{a}} \pm 0.03$ & $0.22^{\mathrm{a}} \pm 0.03$ \\
\hline $\mathrm{t} 3$ & $2016.67^{\mathrm{a}} \pm 123.83$ & $3316.67 \mathrm{a} \pm 115.76$ & $0.26^{\mathrm{a}} \pm 0.01$ & $0.19^{\mathrm{a}} \pm 0.04$ \\
\hline
\end{tabular}

Table 8 shown the effect of feeding mung bean on carcass weight and dressing percentage. at 35 and 42 day. No significant differences were observed in carcass weight and dressing percentage.

Table 8: Carcass weight and dressing percentage influenced by different dietary treatment (mean \pm stander error)

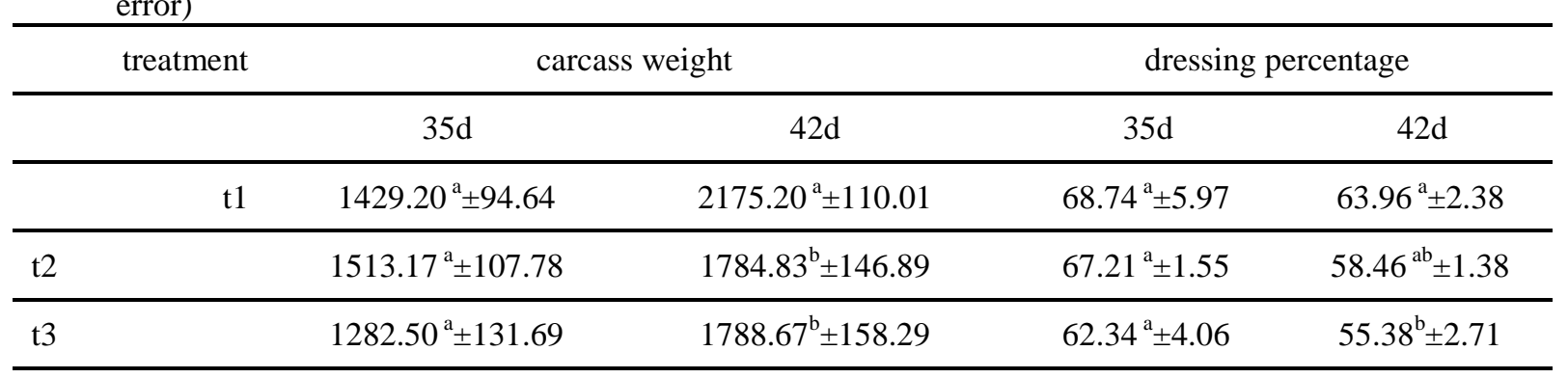

Breast and thigh percentage of broilers at 35 and 42 day are shown in Table9. There was no significant difference in breast meat yield $(P \geq 0.05)$ between treatments.

Table 9: Effect of using mung beans on thigh and Breast percentage of broiler (mean \pm stander error)

\begin{tabular}{lcccc}
\hline treatment & \multicolumn{2}{c}{ thigh } & $35 \mathrm{~d}$ & $42 \mathrm{~d}$ \\
\hline $\mathrm{t} 1$ & $35 \mathrm{~d}$ & $42 \mathrm{~d}$ & $20.83^{\mathrm{a}} \pm 1.75$ & $23.74^{\mathrm{a}} \pm 1.48$ \\
\hline $\mathrm{t} 2$ & $18.70^{\mathrm{a}} \pm 0.90$ & $17.54^{\mathrm{a}} \pm 0.33$ & $23.49^{\mathrm{a}} \pm 0.79$ & $21.16^{\mathrm{a}} \pm 0.73$ \\
\hline $\mathrm{t} 3$ & $16.76^{\mathrm{a}} \pm 0.81$ & $15.84^{\mathrm{a}} \pm 0.38$ & $25.16^{\mathrm{a}} \pm 2.41$ & $22.93^{\mathrm{a}} \pm 1.05^{\mathrm{a}}$ \\
\hline
\end{tabular}

Table 10 shown the effect of feeding mung bean on heart, liver and gizzard percentage with carcass weight at 35 and 42 day. No significant differences were observed in heart, liver and gizzard percentage in 35 and 42 days.

Table 10: The effect of using mung beans on liver, heart and gizzard of broiler (mean \pm stander error)

\begin{tabular}{|c|c|c|c|c|c|c|}
\hline \multirow[t]{2}{*}{ treatment } & \multicolumn{2}{|c|}{ liver } & \multicolumn{2}{|c|}{ heart } & \multicolumn{2}{|c|}{ Gizzard } \\
\hline & $35 d$ & $42 \mathrm{~d}$ & $35 d$ & $42 d$ & $35 d$ & $42 d$ \\
\hline $\mathrm{t} 1$ & $2.37^{\mathrm{a}} \pm 0.16$ & $2.02^{\mathrm{a}} \pm 0.10$ & $0.53^{\mathrm{a}} \pm 0.04$ & $0.51^{\mathrm{a}} \pm 0.04$ & $2.02^{\mathrm{a}} \pm 0.16$ & $1.43^{\mathrm{a}} \pm 0.08$ \\
\hline $\mathrm{t} 2$ & $1.99^{\mathrm{a}} \pm 0.15$ & $1.68^{\mathrm{a}} \pm 0.09$ & $0.57^{\mathrm{a}} \pm 0.04$ & $0.41^{\mathrm{a}} \pm 0.03$ & $1.93^{\mathrm{a}} \pm 0.21$ & $1.61^{\mathrm{a}} \pm 0.09$ \\
\hline $\mathrm{t} 3$ & $2.28^{\mathrm{a}} \pm 0.08$ & $1.78^{\mathrm{a}} \pm 0.15$ & $0.53^{\mathrm{a}} \pm 0.03$ & $0.46^{\mathrm{a}} \pm 0.05$ & $2.17^{\mathrm{a}} \pm 0.15$ & $1.46^{\mathrm{a}} \pm 0.06$ \\
\hline
\end{tabular}




\section{DISCUSSION}

The present results cleared evidence that mung beans, when properly supplemented, will support good growth in broiler chickens at levels up to $40 \%$ of the diet. Raw mung beans do not appear to contain anti nutritional factors such as those found in soybean (Almquist and Merritt, 1952), field or red beans (Kienholz et al., 1962), and lima beans (Rockland and Metzler, 1967). Similar results were obtained by creswell (1980) who found that feeding mung beans had no significant effect on broiler performance.

The effectiveness of these dietary treatments might be due to either changes in gut flora, reduced trypsin activity in the small intestine, antioxidant, membrane stabilizing and/or immunomodulating properties. However, further research is needed to know the exact factor responsible for anticoccidial effect of sprouted mung (Singh, 2013a).

\section{CONCLUSION}

Add the seeds mung beans raw did not show any significant differences in the productive performance of broiler chickens, but did not adversely affect the productive performance

\section{REFERENCE}

Allen, PC.; Danforth, HD. and Augustine, PC. (1998): Dietary modulation of avian coccidiosis. International Journal of Parasitology, 28: 1131-40.

Almquist, H.J. and Merritt, J.B. (1952): Effect of soybean antitrypsin on growth of the chick. Arch. Biochem. Biophys.35: 352-354.

Awika, J.M.; Rooney, L.W. and Waniska, R.D. (2000): Sorghum brans high in ant hocyanins and tannins had higher antioxidant powers than blueberries and garlic. American Association. of Cereal Chemists (AACC) Annual Meeting. Kansas City.

Creswell, D. (1980): Nutritional evaluation of mung beans (phaseolusaureus) for young broiler chickens. Poultry science 60: 1905-1909.

Duncan, D.B. (1955): Multiple range and multiple $\mathrm{f}$ test. Biometrics. 11: 1-42.
Frolich, S.; Farhat, J. and Wallach, M. (2013): Designingstrategies for the control of coccidiosis in chickens on poultry farms using modern diagnostic tools. Reports in Parasitology, 3: 1-10.

Kienholz, E.W.; Jensen, L.S. and Mcginnis, J. (1962): Evidence for chick growth inhibitors in several legume seeds. Poultry sci. 41: 367-371.

McNaughton, J.L. (1978): Effect of dietary fiber on egg yolk, liver, and plasma cholesterol concentrations of the laying hen. Journal of Nutrition. 108: 1842-8.

Murwani, R. (2010): Effect of MOS, Baker Yeast, or Noni Leaves Extracts on Antibody Titers to. NDV and AI Vaccine of Broilers Fed Cornmungbean Base Diets nternational Journal of Poultry Science 9 (9): 890-894.

Murwani, R. and Murtini, S. (2009): Effect of Chlortetracyclin additive in broilers fed local diets on antibodytiters to NDV vaccine. Int. J. Poult. Sci., 8: 755-759

Murwani, R. (2008): Effect of corn or sorghum in Combination with soybean meal or mung bean as feeding redients on the serum antibody titres to NDV vaccine in broiler chickens. Int. J. Poult. Sci., 7: 497-501.

Rockland, L.B. and Metzler, E.A. (1967): Quick cooking lima beans and other dry beans. Food technol. 21(3a): 26a-30a.

Singh, V.S.; Jyoti Palod; Stuti Vatsya; Rajeev Ranjan Kumar and Shukla, S.K. (2013a): Effect of sprouted mung bean (Vignaradiata) supplementation on performance of broilers during mixed Eimeria species infection. RGANIC CHROMIUM ON EIMERIASP. Veterinary Research International .Vol 1 | \begin{tabular}{l|ll} 
Issue 2 & Pages 41-45 VETERINARY
\end{tabular} RESEARCH INTERNATIONAL Journal homepage: www.jakraya.com/journ.

Singh, VS.; Palod, J.; Vatsya, S. and Shukla, SK. (2013b): Effect of herbal vitamin E-selenium with organic chromium on growth, haematological and parasitological parameters of broiler chicken during mixed Eimeria infection. Veterinary Research International, 1(1): 25-30.

Vegad, JL. (2004): Poultry Diseases. International Book Distributing Company, Lucknow.

Xl stat, version 7.5. (2004): (addinsoft, 2005). Addinsoft. 2005. Xlstat pro version 7.5.3. Http: // www. Xlstat.com/en/ho. 
تاثير تغذية بذور الماش الخام على الاداء الانتاجي لفروج اللحم

رونكار بايز سعبي

قسم الانتاج الحيو اني ، فاكلتي العلوم الزر اعية ، جامعة السليمانية ، اقليم كردستان العراق

Email: rozhgarbayzesaeed@yahoo.com Assiut University web-site: www.aun.edu.eg

أجريت هذه الدر اسة في حقول الدو اجن التابعة لمديرية الحقول الزر اعية/ فاكلتي العلوم الزر اعية/ جامعة السليمانية في منطقة بكرجو،

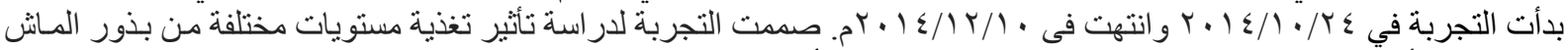

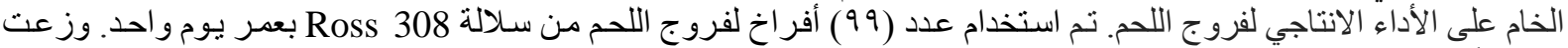

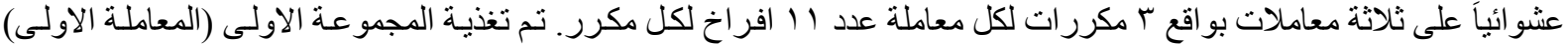

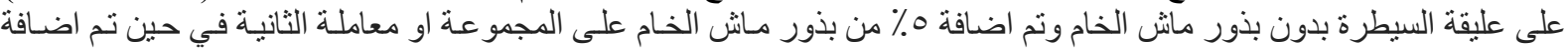

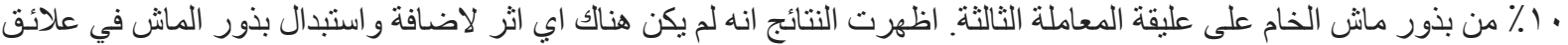

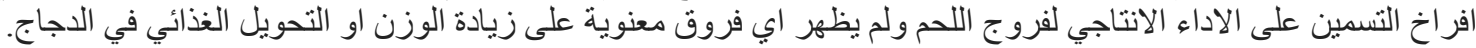

